\title{
Nutritional Potential of Acacia (Acacia Nilotica (L.) Del.) Pods for Growing Red Sokoto Goats
}

\author{
Uguru, C., Lakpini, C.A.M., Akpa, G.N., And Bawa, G.S. \\ Department Of Animal Science, Faculty Of Agriculture, Ahmadu Bello University, Zaria
}

\begin{abstract}
An experiment to evaluate the potentials of Acacia nilotica pods as replacement for cotton seed cake (CSC) on nutrients digestibility, haematological parameters and growth performance of Red Sokoto goats was conducted. The aim was to explore the possibility of reducing the high cost of feeding goats by using alternative source of protein instead of the highly demanded and costly conventional sources of protein like CSC. Twenty five Red Sokoto goats (bucks) having average age of 10 months, and average weight of $10.3 \pm 0.1 \mathrm{~kg}$ were blocked to balance for weight in a Completely Randomized Block Design (CRBD) experiment, and assigned to 5 treatments having 5 animals per treatment. They were fed graded levels of sun-dried Acacia pods as replacement for CSC, and dried sweet potato forage as basal diet. The proximate analysis of the diets compounded with graded levels of sun-dried Acacia pods with other feed ingredients showed that zero inclusion of Acacia pods (control), had the highest percentage of crude protein $(C P) 17.56 \%$. The percentages of CP decreased in the diets as the level of Acacia pods inclusion increased. The control diet also had the highest percentage of dry matter (DM) $94.41 \%$, while the least value of DM was recorded in 100\% Acacia pods level (93.21\%). The levels of metabolizable energy (ME) in the diets ranged from 2322 to $2549 \mathrm{ME}$ (Kcal/kg). While the crude fibre $(C F)$ in the diets ranged from 10.72 to $14.26 \%$. There were no significant $(P>0.05)$ differences in daily feed intake (DFI) and final body weight (FBW) in Red Sokoto goats fed graded levels of sun-dried Acacia pods. There were significant $(P<0.05)$ differences in weight gain $(W G)$, daily weight gain $(D W G)$, feed conversion ratio $(F C R)$ and cost per weight gain (CPWG) across the treatments. Goats fed $25 \%$ level of sundried Acacia pods performed better than the other animals in the other treatments in terms of WG, DWG, FBW and had the cheapest cost per weight gain in Naira $(\# / k g)$. There were significant $(P<0.05)$ differences in the digestibility of most of the feed nutrients and in water intake (WI) in the treatments. Also there were significant $(P<0.05)$ differences in all the blood parameters (Packed Cell Volume (PCV), Haemaglobin (Hb), Total Plasma Protein (TPP), Plasma Urea Nitrogen (PUN), and Creatinine (Cr)) measured in this experiment. It was therefore, concluded that 25\% of sun-dried Acacia pods can be used to replace CSC in the diets of Red Sokoto goats without having any adverse effect on nutrients digestibility, blood parameters and their performance. Acacia pods can also be used to significantly reduce the high cost expended in feeding goats with conventional sources of protein and to increase availability of animal protein, as well as increase the profit margin of goat farmers.
\end{abstract}

\section{Introduction}

The most difficult constraint in small ruminant production in the tropics is the inadequacy and poor quality of the available energy and protein feed stuffs, particularly during the dry season (Njoya, et al., 2005; Olafadehan, et al., 2009).

The above situation according to Ademosun (1985) and Topps (1992) calls for search for cheaper and locally available alternative feed stuffs which should be nutritionally viable, non-toxic and of little or no dietary value in human diets. Acacia species (including Acacia nilotica pods) meet all the above requirements, except that it requires one form of processing or the other to reduce the amount of anti-nutritional factors (tannins) in them (Mokoboki, et al., 2005).

Acacia nilotica has great potential for feeding livestock, especially during period of drought and feed scarcity (Tanner, et al., 1990; Sawe, et al., 1998). However, notwithstanding its availability in Nigeria, especially in the northern states and its great potential for feeding livestock; its use for feeding livestock is still very low. In Nigeria, it is mainly used for leather tanning, and to a lesser extent for medicinal purposes and for the control of erosion in desert prone areas.

Tannin in Acacia species can be greatly reduced by subjecting them to processing in various ways, by soaking pods in polyethylene glycol (PEG), boiling pods in water, adding charcoal to pods, crushing and soaking pods in wood ash $(\mathrm{NaOH})$ or ammonia solutions $\left(\mathrm{NH}_{3}\right)$ or by sun-drying (Poage, et al., 2000; Mlambo et al., 2001; Rubanza, et al., 2003; Sikosana, et al., 2006). Most of the above methods of processing Acacia pods are either too technical, expensive or harmful to man and livestock, particularly when used wrongfully. In this experiment, Acacia pods processed by sun-drying for 7 days (a relatively safer, cheaper and less harmful 
method) were used in the diets of Red Sokoto goats to replace CSC at different graded levels; to evaluate its effect on the digestibility of nutrients, blood parameters and growth performance of Red Sokoto goats.

\section{Materials And Methods}

\section{Experimental Site}

The experiment was conducted in the experimental unit of the Small Ruminant Research Programme of the National Animal Production Research Institute, Ahmadu Bello University, Shika, Zaria. Shika is located in the northern guinea savannah on latitude $11^{\circ} 12^{\prime} \mathrm{N}$ and longitude $7^{0} 33^{\prime} \mathrm{E}$, at altitude of $610 \mathrm{~m}$ above sea level. Annual rainfall is about 1100 to $1200 \mathrm{~mm}$, while mean temperature is about $24.4^{\circ} \mathrm{c}\left(14.5\right.$ to $39.3^{0} \mathrm{c}$ ), with the lowest temperature occurring during early dry season (November - January). Higher temperatures are experienced during the late dry season, from February to April (Google Earth, 2012).

\section{Proximate and Chemical Analysis of Feeds}

Samples of feeds formulated with sun-dried Acacia nilotica pods to replace CSC at 0-100\% levels were collected and chemically analyzed to determine their DM, CP, CF, Ether extract (EE) and Ash contains using AOAC (2000) method. Hemicellulose (HC), Acid detergent fibre (ADF) and Neutral detergent fibres (NDF) were determined by the method of Van Soest and Robertson (1998). While urine sample were analyzed for their nitrogen contents using Archer and Robb (1925) method.

\section{Animals Management, Feeds and Feeding}

Twenty five Red Sokoto goats (bucks) of average age of 10 months and weighing on average $10.3 \pm 1.0 \mathrm{~kg}$ were used for this experiment. The animals were bought from local markets within Zaria and Makarfi, in Kaduna State, Nigeria. The animals were given prophylactic treatments against endo-parasites, ectoparasites and bacterial infections 7 days before commencement of experiment. They were dewormed with Albendazole ${ }^{\circledR}$ to control endo-parasites at $3 \mathrm{ml} / 10 \mathrm{~kg}$ body weight (BW) repeated after 2 weeks, Ivomectin (Ivomec $®$ ) to control ecto-parasites at $0.5 \mathrm{ml} / 25 \mathrm{~kg} \mathrm{BW}$ given subcutaneously and long-acting antibiotics (Tridox ${ }^{\circledR}$ ) oxy-tetracycline injection to control bacteria at $1.0 \mathrm{ml} / 10 \mathrm{~kg} \mathrm{BW}$ given intramuscularly and repeated after 3 days.

The animals were blocked according to their weight and assigned to 5 treatments each having 5 animals. The animals were individually penned and offered the experimental diets made up of sun-dried Acacia pods with other feed ingredients: maize offal, CSC, bone meal, salt and sun-dried sweet potato forage as basal diet. Each animal received a total of $4 \%$ of their body weight as daily feed allowance. Out of this total, $40 \%$ and $60 \%$ were provided by the experimental diets and dried sweet potato forage respectively. The experimental diets were given at 08.00 hours, while the sun-dried sweet potato forage was given 3 hours later. The left-over feed from each animal was measured the following day before feeding them. Water was also provided free-choice to animals, and the feeding trial lasted for 90 days.

\section{Measurements}

Data on feed intake, water intake, weekly live weight of animals, blood samples, urine production and samples of feeds offered and feacal output were collected and recorded for chemical and statistical analysis.

\section{Design/Analysis Of Data}

The experiment was a Completely Randomized Block Design (CRBD). Data generated from the experiment were analyzed using the General Linear Model (GLM) analysis of variance procedure of Statistical Analytical System (SAS, 2005). Treatment means that were significantly different were separated using Duncan's Multiple Range Test (DMRT).

\section{Results And Discussion}

The chemical composition of diets containing different levels of sun-dried Acacia pods as replacement for cotton seed cake are presented in Table 1 .

Table 1: Chemical Composition of Diets Containing different levels of Sun-dried Acacia nilotica Pods as Replacement for Cotton Seed Cake (Expt. II)

\begin{tabular}{llllll}
\hline \multicolumn{7}{c}{ Treatments (Levels of $\boldsymbol{A}$. nilotica) } \\
\hline Parameters (\%) & $\mathbf{0}$ & $\mathbf{2 5}$ & $\mathbf{5 0}$ & $\mathbf{7 5}$ & $\mathbf{1 0 0}$ \\
Dry Matter & 94.41 & 94.21 & 93.62 & 93.69 & 93.21 \\
Ash & 6.97 & 6.08 & 4.53 & 4.90 & 4.24 \\
Crude Protein & 17.56 & 17.50 & 15.38 & 14.50 & 14.38 \\
Crude Fibre & 10.72 & 13.13 & 14.26 & 13.71 & 14.13 \\
Ether Extract & 18.28 & 18.29 & 13.48 & 10.68 & 13.92 \\
NDF & 45.98 & 29.48 & 28.20 & 41.57 & 28.64
\end{tabular}




\begin{tabular}{cccccc}
\hline & & & & \\
ADF & 10.66 & 12.01 & 16.68 & 11.47 & 14.11 \\
$\mathrm{HC}$ & 35.32 & 17.47 & 11.52 & 30.10 & 14.53 \\
$* \mathrm{ME}(\mathrm{Kcal} / \mathrm{kg})$ & 2536 & 2322 & 2430 & 2549 & 2428 \\
\hline
\end{tabular}

$* \mathrm{ME}=0.0152(\overline{\mathrm{DCP}})+0.0342(\mathrm{DEE})+0.0128(\mathrm{DCF})+0.0159(\mathrm{DNFE})$.

According to: Alderman G. (1978).

The above result showed that zero inclusion of sun-dried Acacia pods gave better results in terms of total DM, $94.41 \%, \mathrm{CP}, 17.56 \%$ and had the least percentage of CF, $10.72 \%$. Also $25 \%$ inclusion of acacia pods gave good results in terms of total DM, CP and CF $94.21 \%, 17.50 \%$ and $13.13 \%$ respectively. In addition, the percentage of hemicelluloses (HC) $17.47 \%$ in $25 \%$ Acacia pods inclusion level was lower than the value of $35.32 \%$ recorded in zero percent Acacia pods inclusion. The CP values of the feeds $14.38 \%$ to $17.56 \%$ fall within the range of 12 to $30 \%$ reported by Norton (1998) for most tropical legumes and the range of 10 to $15 \%$ reported by Sikosana et al., (2002) for most browse plants. Similarly, Leng (1990) reported that the minimum $\mathrm{CP}$ content for rumen functions is $7-8 \%$.

The performance of Red Sokoto goats fed diets containing different levels of sun-dried Acacia nilotica pods to replace cotton seed cake are presented in Table 2.

Table 2: Performance of Red Sokoto Goats Fed Diets Containing Different Sun-Dried Acacia nilotica Pods to Replace Cotton Seed Cake

Treatments (\% Levels of Acacia nilotica replacement of CSC)

\begin{tabular}{|c|c|c|c|c|c|c|c|}
\hline Parameters & $\mathbf{0}$ & 25 & 50 & 75 & 100 & SEM & LOS \\
\hline Initial Body Weight (kg) & 10.30 & 10.40 & 10.30 & 10.30 & 10.40 & 1.20 & NS \\
\hline Final Body Weight (kg) & 16.30 & 16.62 & 15.62 & 14.14 & 14.94 & 1.92 & NS \\
\hline Daily Intake of Exp. diet (g) & 256.93 & 262.16 & 249.97 & 228.94 & 225.30 & 29.87 & NS \\
\hline Daily Sweet Potato Intake (g) & 342.80 & 339.71 & 331.34 & 316.22 & 330.42 & 31.50 & NS \\
\hline Daily Feed Intake (g) & 599.73 & 601.87 & 581.31 & 545.16 & 555.72 & 59.82 & NS \\
\hline Weight Gain $(\mathrm{kg})$ & $6.00^{\mathrm{a}}$ & $6.22^{\mathrm{a}}$ & $5.32^{\mathrm{ab}}$ & $3.84^{\mathrm{b}}$ & $4.54^{\mathrm{b}}$ & 0.86 & $*$ \\
\hline Daily Weight Gain (g) & $66.67^{\mathrm{a}}$ & $69.11^{\mathrm{a}}$ & $59.11^{\mathrm{ab}}$ & $42.67^{\mathrm{b}}$ & $50.44^{\mathrm{ab}}$ & 9.61 & $*$ \\
\hline Feed Conversion Ratio & $8.99^{c}$ & $8.70^{\mathrm{c}}$ & $9.83^{\mathrm{bc}}$ & $12.77^{\mathrm{a}}$ & $11.01^{\mathrm{b}}$ & 0.84 & $*$ \\
\hline Cost/Weight Gain (N/kg) & $0.61^{\mathrm{ab}}$ & $0.55^{\mathrm{a}}$ & $0.59^{\mathrm{a}}$ & $0.71^{\mathrm{b}}$ & $0.56^{\mathrm{a}}$ & 0.04 & $*$ \\
\hline
\end{tabular}

$\mathrm{a}, \mathrm{b}, \mathrm{c}$ means in the same row bearing different superscripts are significantly different $(\mathrm{P}<0.05)$ level, * $=$ significant at $\mathrm{P}<0.05$; and $\mathrm{NS}=$ not significant at $\mathrm{P}>0.05$.

There were no significant differences in many of the parameters measured. However, daily intake of experimental diets declined as the level of Acacia pods inclusion increased from $262.16 \mathrm{~g}$ in $25 \%$ Acacia pods level to $225.30 \mathrm{~g}$ in $100 \%$ Acacia pods level. The above result agrees with the finding of Makaranga (2002) who reported reduction in DM intake and CP intake in sheep fed browse diets containing tannins. However, Araya $e t$ al., (2003) reported that DM intake, percent in-vitro dry and organic matter digestibilities and body weight gains increased with an increase in the amount of $A$. tortilis pods in the rations of goats, up to $75 \%$ level before declining. The total daily feed intake (TDFI) across the treatments did not vary significantly, but the highest TDFI of $601.87 \mathrm{~g}$ recorded in $25 \%$ Acacia pods level was below the values of $768.40 \mathrm{~g}$ and $790 \mathrm{~g}$ for goats fed $A$. fleckii and A. tortilis respectively as supplements (Aganga et al., 1998). The above differences may be attributed to nutritional differences common in species of Acacia and on the methods of processing used.

Weight gain (WG) differed significantly across the treatments, and the highest WG of $6.22 \mathrm{~kg}$ recorded in $25 \%$ Acacia pods inclusion was similar to the value of $6.23 \mathrm{~kg}$ reported by Yahaya (2011) when varied levels of A. seyal del. Was fed to sheep as supplement.

The nutrients digestibilities and nitrogen balance in Red Sokoto goats fed different levels of sun-dried Acacia nilotica pods as replacement for cotton seed cake are presented in Table 3.

Table 4.10: Nutrients Digestibilities and Nitrogen Balance in Red Sokoto

Goats Fed different levels of Sun- dried Acacia Nilotica Pods as replacement for Cotton Seed Cake.

\begin{tabular}{|c|c|c|c|c|c|c|c|}
\hline \multirow[b]{2}{*}{ Parameters (\%) } & \multicolumn{7}{|c|}{ Treatments (\% Levels of $A$. nilotica replacement of CSC). } \\
\hline & $\mathbf{0}$ & 25 & 50 & 75 & 100 & SEM & LOS \\
\hline $\mathrm{DM}$ & $55.50^{\mathrm{ab}}$ & $55.55^{\mathrm{a}}$ & $55.47^{\mathrm{ab}}$ & $55.38^{\mathrm{b}}$ & $55.39^{b}$ & 0.033 & $*$ \\
\hline $\mathrm{CP}$ & $51.94^{\mathrm{a}}$ & $50.69^{\mathrm{b}}$ & $51.57^{\mathrm{ab}}$ & $50.57^{\mathrm{b}}$ & $51.88^{\mathrm{ab}}$ & 0.293 & $*$ \\
\hline Ash & $57.63^{\mathrm{a}}$ & $55.63^{\mathrm{b}}$ & $56.79^{\mathrm{ab}}$ & $51.18^{\mathrm{d}}$ & $53.49^{c}$ & 0.709 & $*$ \\
\hline $\mathrm{EE}$ & $28.52^{\mathrm{a}}$ & $23.56^{\mathrm{c}}$ & $25.80^{\mathrm{b}}$ & $25.89^{\mathrm{b}}$ & $24.83^{c}$ & 0.849 & $*$ \\
\hline $\mathrm{CF}$ & $22.52^{\mathrm{b}}$ & $24.01^{\mathrm{a}}$ & $22.30^{\mathrm{b}}$ & $23.18^{\mathrm{ab}}$ & $21.90^{\mathrm{b}}$ & 0.371 & $*$ \\
\hline NDF & $33.47^{\mathrm{ab}}$ & $34.18^{\mathrm{a}}$ & $33.05^{\mathrm{b}}$ & $33.77^{\mathrm{ab}}$ & $33.32^{\mathrm{b}}$ & 0.194 & $*$ \\
\hline $\mathrm{ADF}$ & $29.20^{\mathrm{a}}$ & $30.24^{\mathrm{a}}$ & $28.75^{\mathrm{ab}}$ & $28.39^{\mathrm{b}}$ & $28.74^{\mathrm{ab}}$ & 0.321 & $*$ \\
\hline $\mathrm{HC}$ & $30.36^{\mathrm{c}}$ & $27.60^{\mathrm{d}}$ & $30.11^{\mathrm{c}}$ & $37.64^{\mathrm{a}}$ & $32.05^{\mathrm{b}}$ & 1.700 & $*$ \\
\hline Water Intake $(\mathrm{ml} / \mathrm{d})$ & $6922.5^{\mathrm{a}}$ & $6300.0^{\mathrm{ab}}$ & $5247.5^{\mathrm{b}}$ & $6481.3^{\mathrm{ab}}$ & $5366.3^{\mathrm{b}}$ & 454.6 & $*$ \\
\hline
\end{tabular}


Nutritional Potential of Acacia (Acacia Nilotica (L.) Del.) Pods for Growing Red Sokoto Goats

\begin{tabular}{|c|c|c|c|c|c|c|c|}
\hline $\mathrm{N}$ Intake (g/day) & $234.67^{\mathrm{a}}$ & $211.09^{\mathrm{ab}}$ & $206.86^{\mathrm{ab}}$ & $182.60^{\mathrm{b}}$ & $176.03^{\mathrm{b}}$ & 21.67 & $*$ \\
\hline Faecal N (g/day) & $78.71^{\mathrm{a}}$ & $75.29^{\mathrm{a}}$ & $73.43^{\mathrm{a}}$ & $53.43^{\mathrm{b}}$ & $51.01^{\mathrm{b}}$ & 7.78 & $*$ \\
\hline Urinary N (g/day) & $31.06^{\mathrm{ab}}$ & $22.76^{\mathrm{ab}}$ & $28.60^{\mathrm{ab}}$ & $36.11^{\mathrm{a}}$ & $14.32^{\mathrm{b}}$ & 10.39 & $*$ \\
\hline N-Retained (g/day) & 124.90 & 113.04 & 104.83 & 93.06 & 110.70 & 22.02 & NS \\
\hline$\%$ of Intake retained & 53.22 & 53.55 & 50.68 & 50.96 & 62.89 & 8.05 & NS \\
\hline
\end{tabular}

$\mathrm{a}, \mathrm{b}, \mathrm{c}$ means bearing superscripts in a row differ significantly, SEM = Standard Error of Means, LOS = Level of Significance at $\mathrm{P}<0.05$, NS = Not significant.

The result of nutrient digestibilities and nitrogen retention showed significant differences in most of the parameters measured except nitrogen retention and percentage of intake retained. Water intake (WI) was highest in zero inclusion of Acacia pods $6922.5(\mathrm{ml} / \mathrm{d})$, this may have been because of the oily and fibrous nature of CSC, as well as the high level of hemicelluloses (35.32\%) in diets containing zero percent Acacia pods.

Nitrogen intake (NI) in grammes per day differed significantly across the treatments and followed a defined pattern. It decreased as the level of Acacia pods inclusion increased from $0-100 \%$. The above agrees with the finding of Salem et al., (2006), they reported that ingestion of tannin containing food by ruminants may reduce digestibility of nutrients (particularly protein) and will affect voluntary intake of nutrients.

Feacal nitrogen (FN) also differed significantly across the treatments; it decreased as the level of Acacia pods inclusion increased from 0-100\%. This result did not agree with the findings of Van Soest (1994) and Karda et al., (2001); they reported that increasing levels of tannin in diets of animals will also lead to increase in FN excretion because of low digestibility of nitrogen and the formation of tannin protein complexes.

Urinary Nitrogen (UN) differed significantly across the treatment from14.32-36.11\%. This result did not agree with the findings of Van Soest (1994), and Kaitho et al., (1998), they reported that animals on high tannin diets retained more nitrogen by reducing nitrogen excretion through urine. However, in this study nitrogen excretion through urine was high for animals that received $25 \%$ to $75 \%$ Acacia pods in their diets. Reduction of nitrogen excretion in the urine as reported by Van Soest (1994) and Kaitho et al., (1998) was only remarkable at $100 \%$ inclusion of Acacia pods in the diet.

Percent nitrogen retention (NR) did not differ significantly amongst the experimental animals; nitrogen retention decreased as the level of Acacia pods inclusion increased up to $75 \%$ and rose again at $100 \%$ Acacia pods level. The above did not agree with the findings of Van Soest (1994), Umunna et al., (1995) and Kaitho et al., (1998); they reported that high level of tannin may cause low apparent digestibility of nitrogen, but this may not always lead to decrease nitrogen retention as tannin in the diet increases, because of decreased urinary nitrogen excretion. A possible explanation for the poor NR in this experiment may be the high levels of UN recorded at $25-75 \%$ Acacia pods inclusion levels.

The results of Haematological parameters of Red Sokoto goats fed graded levels of sun-dried Acacia pods as replacement for cotton seed cake at different hours of sampling are presented in a trend analysis in Figures 1-5.

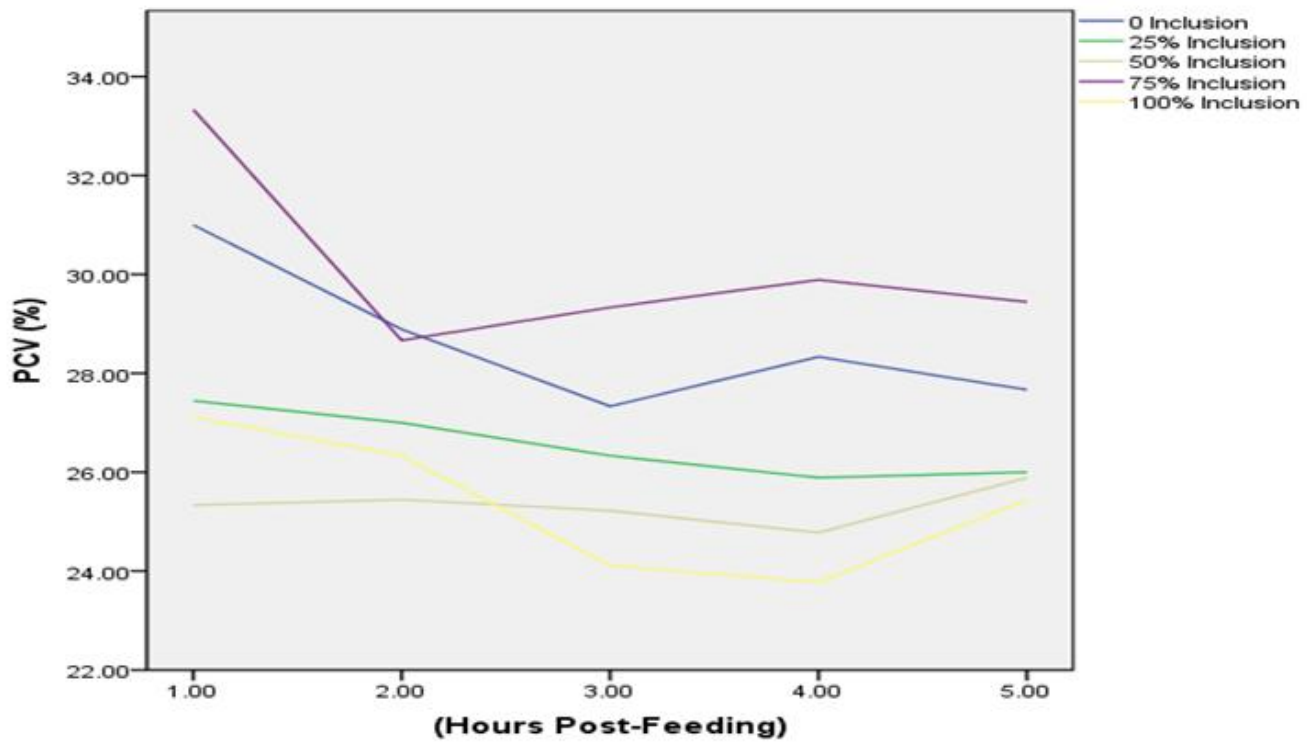

Fig 1: Trend of PCV (\%) of Red Sokoto Goats fed graded levels of Acacia nilotica pods at different hours of collection. 


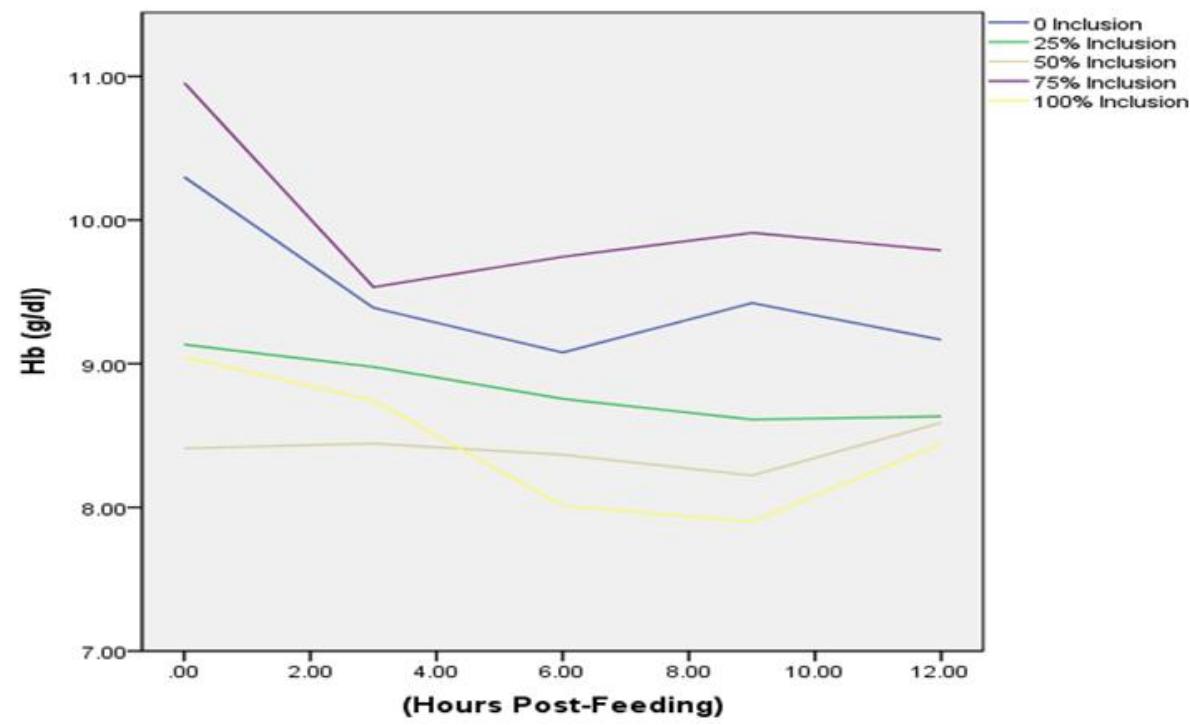

Fig 2: Trend of $\mathrm{Hb}$ (g/dl) of Red Sokoto Goats fed graded levels of Acacia nilotica pods at different hours of collection.

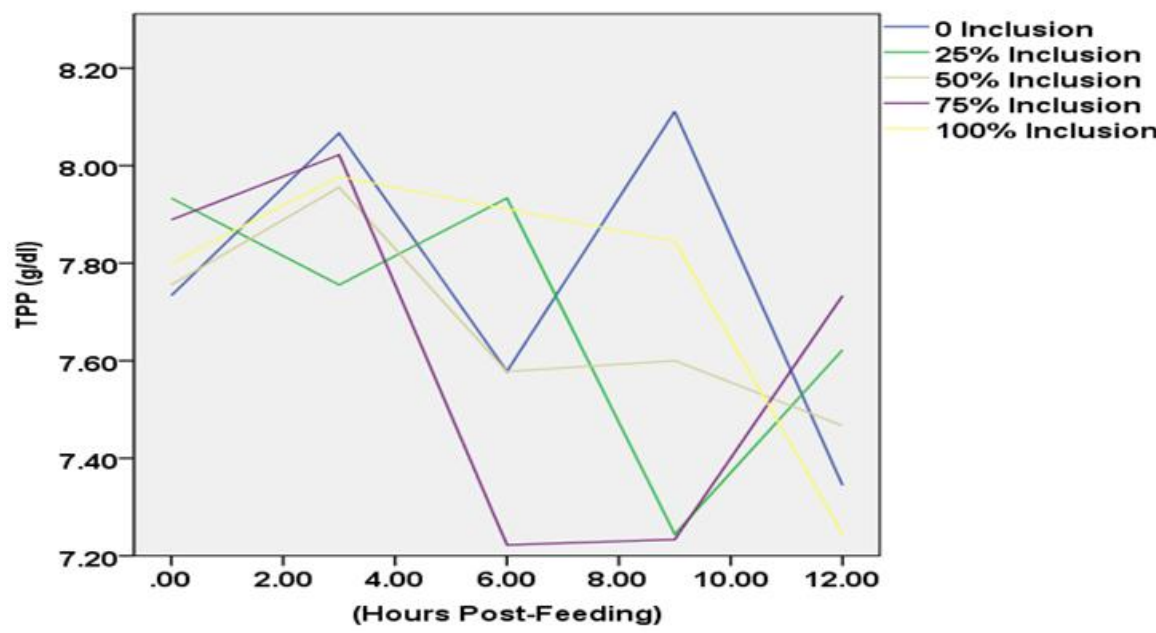

Fig 3: Trend of TPP (g/dl) of Red Sokoto Goats fed graded levels of Acacia nilotica pods at different hours of collection.

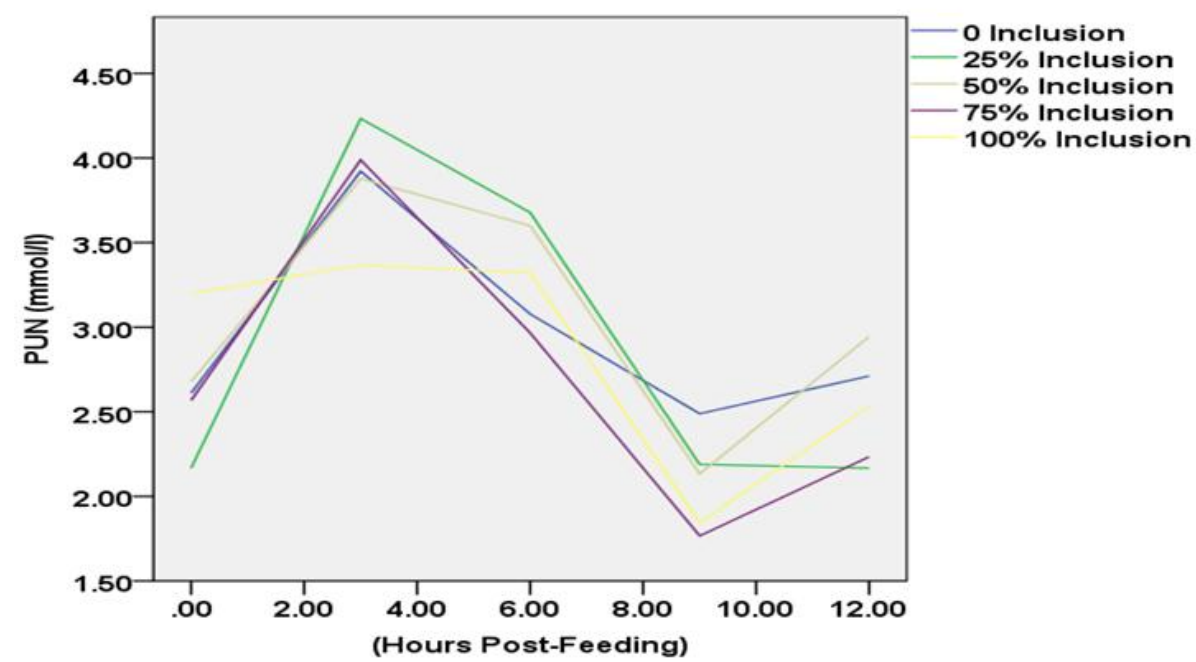

Fig 4: Trend of PUN (Mmol/l) of Red Sokoto Goats fed graded levels of Acacia nilotica pods at different hours of collection. 


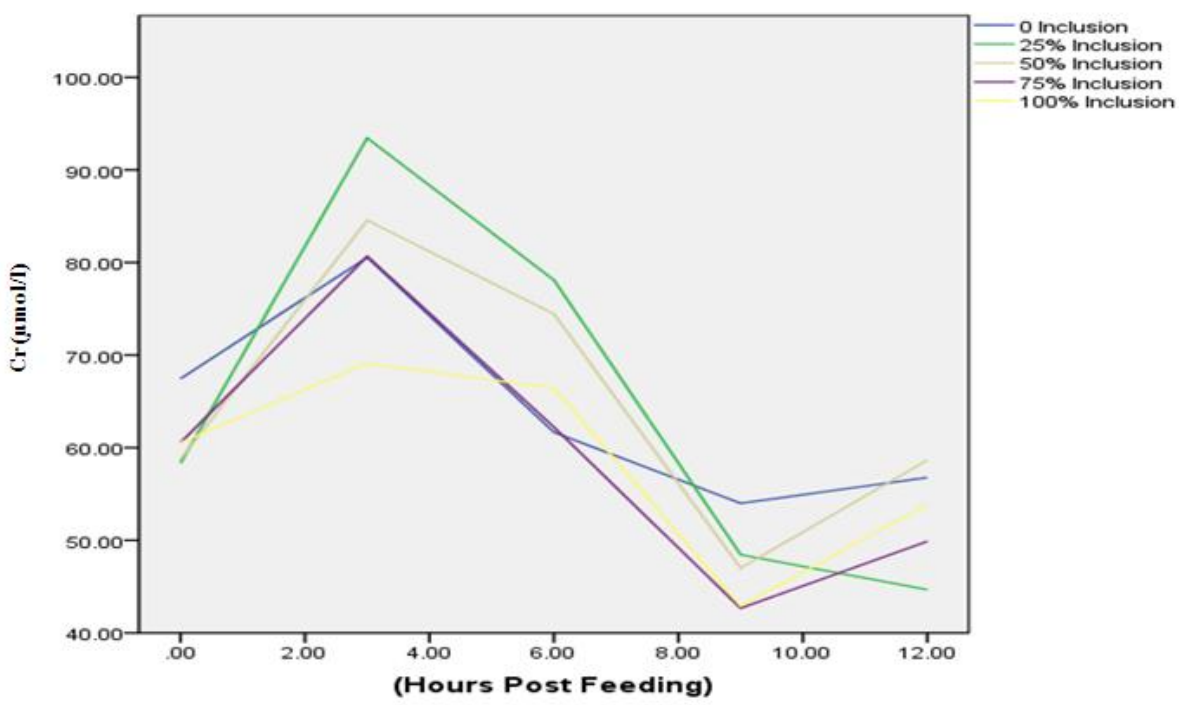

Fig 5: Trend of $\mathrm{Cr}(\mu \mathrm{mol} / \mathrm{l})$ of Red Sokoto Goats fed graded levels of Acacia nilotica pods at different hours of collection.

The results showed significant differences in all the parameters measured. The range of PCV, $\mathrm{Hb}$ and TPP, 23.53 to $33.20 \%, 7.79$ to $11.03 \mathrm{~g} / \mathrm{dl}$ and 6.48 to $8.58 \mathrm{~g} / \mathrm{dl}$ fall within the range of PCV (24 to $45 \%$ ), $\mathrm{Hb}$ (8 to $15 \mathrm{~g} / \mathrm{dl}$ ) recommended for goats by Ganti (1983). Also the level of TPP recorded in this study was within the range of 6.4 to $7.0 \mathrm{~g} / \mathrm{dl}$ recommended for the caprine species by Kaneko (1989). However, the range of PUN, 1.84 to $4.45 \mathrm{mmol} / \mathrm{l}$ and $\mathrm{Cr}, 41.93$ to $87.87 \mu \mathrm{mol} / 1$ were below the range of 2.5 to $6.5 \mathrm{mmol} / 1$ of PUN recommended for goats by Mehrez (1976); and the range of $\mathrm{Cr}, 88.40$ to $159.00 \mu \mathrm{mol} / \mathrm{l}$ recommended for goats by Kaneko et al., (1997).

While the low levels of PUN recorded in this experiment agrees with the finding of Reed et al., (1990) who reported that high levels of tannins in the diets affect the level of PUN in the blood negatively; the levels of Cr recorded in this experiment may be described as good, this agrees with the finding of Wisloff et al., (2003), they reported that high levels of $\mathrm{Cr}$ in the blood may be caused by poor filtration in the kidneys due to muscle catabolism when the kidneys are either weak or diseased.

\section{Conclusion}

From the above results and findings, the following conclusions are made:

- Sun-dried Acacia nilotica pods can be used as alternative source of protein in the feeding of Red Sokoto goats.

- Cost of production in Red Sokoto goats can be greatly reduced by replacing CSC in their diets with $25 \%$ sun-dried Acacia nilotica pods

\section{References}

[1]. Ademosun, A.A. (1985). Contribution of Research to Small Ruminant Production in Nigeria. Proc. of the National Conference on Small Ruminant Production held in Zaria, Nig. $6^{\text {th }}-10^{\text {th }}$ Oct. pp. 18-34

[2]. Aganga, A.A., Tsopito, C.M. and Adogla-Bessa, T. (1998). Potential of Acacia Species to Ruminants in Botswana. Arch. Zootec. 47: 659-668

[3]. Alderman G. (1978). A Practical Feeding System for Ruminants. Proceeding of Australian Society of Animal Production.

[4]. AOAC (2002). Association of official methods of Analysis, $17^{\text {th }}$ ed. Association of official Analytical Chemists. Washington, D.C

[5]. Araya, M.R., Ngugi, R.K., Musimba, N.K.R. and Nyariki, D.M. (2003). Effects of Acacia tortilis pods on Intake, Digestibility and Nutritive quality of goat diets in South-Western Eritrea. African journal of range and forage sci. 20 (1): 59-62.

[6]. Archer, H.E., and Robb, G.D. (1925). Blood Urea Analysis. In: Tarnoky, A.L. (ed) Clinical Biochemical Methods. Hilger and Watts Limited, London. Pp. 203-205.

[7]. Ganti, A.S. (1983). Veterinary Clinical Pathology, CBS Publishers.

[8]. Google Earth (2012). Google Location Map; Google Earth Imagery; date September $16^{\text {th }}, 2012$.

[9]. Kaitho, R.J., Umunna, N.N., Nsahlai, I. V., Tamminga, S. and Bruchem, J.V (1998). Utilization of browse supplements with varying tannin levels by Ethopian Menz sheep. Agro forestry System. 39: 145-159.

[10]. Kaneko, J.J (1989). Clinical Biochemistry of Domestic Animals, ed.4, New York, Academic Press

[11]. Kaneko, J.J., Harvey, H.W and Brass, M.L. (1997). Effects of Leucaena supplementation level and provision of Urea on utilization by Sheep of Rhodes grass hay; Australian Journal of Experimental Agriculture 41:155-160.

[12]. Karda, I.W., Dryden, G., and McL. (2001). Effects of Lencaena Supplementation level and Provision of Urea by Sheep of Rhodes Grass Hay; Australian Journal of Experimental Agriculture 41:155-160.

[13]. Leng, R.A (1990). Factors affecting the utilization of poor quality forages by ruminants, particularly under tropical conditions. Nutrition Res. Review 3:277-303. 
[14]. Makaranga, M. (2002). The Effects of Feeding Tannin-Ferrous Rich-Browse Diet to Worm Infected Goats on Crude Protein Digestibility and worm burden. A Special Project. Sokoine University of Agriculture, Tanzania. Pp 23

[15]. Mehrez, A.Z. (1976). A study of the artificial bag technique for determining digestibility of feeds in the rumen. J. Agric. Sci (Camb.), 88:645-650.

[16]. Mlambo, V., Mould, F., Owen, E., Smith, T., Muller-Harvey, I. and Sikosana, J.L.N. (2001). Chemical Composition and in vitro fermentation characteristics of acacia and other tree pods. In: Smith and Geoffrey, S. (editors). Sustaining livestock in challenging environments: strategies for small scale farmers. Proceedings of the third workshop on livestock production programme projects. Ingwe lodge and ICRISAT, Matopos, 26-28 sept. 2000. NRI.

[17]. Mokoboki, H.K., Ndlovu, L.R, Ngambi, J.W., Malatje,M.M. and Nikolova, R.V. (2005). Nutritive value of acacia tree foliages growing in the Limpopo province of South Africa. South African Journal of Anim Sci. 35 (4).

[18]. Njoya, A., Awa, D.N., and Chupamom, J. (2005). The Effects of a Strategic Supplement and Prophylactic on the Reproductive Performance of Primiparous Fulbe Ewes in the Semi-Arid Zone of Cameroun. Small Ruminant Research, 56 (1-3): 21-29.

[19]. Norton, B.W. (1998). The nutritive value of tree legumes. In: Gutteridge, R.C. Shelton, H.M. (eds). Forage tree legumes, in tropical Agriculture, Grass land society of Australia Inc. St. Lucia, Queensland.

[20]. Olafadehan, O.A., Olafadahen, O.O., Obun, C.O., Yusuf, A.M., Adeniji, A.A., Olayinka, O.O and Abdullahi, B. (2009). Global economic recession and the challenges to livestock production in Nigeria. Proc. of the $14^{\text {th }}$ annual confr. of Animal Science Association of Nigeria held at Ladoke Akintola University of Technology, Ogbomoso. Pp 572-574.

[21]. Poage, G.W., Scott, C.B., Bisson, M.G., and Hartamann, F.S. (2000). Activated charcoal attennates bitter weed (Hymenoxys odorata) Toxicosis in sheep. J. Range manage. 53:73-78.

[22]. Reed, J.D., Soller, H. and Woodward, A. (1990). Fodder Tree and Straw Diets for Sheep: Intake, growth, digestibility and the Effect of Phenolics on Nitrogen Utilization. Animal Feed Sci. and Technology, 30: 39-50.

[23]. Rubanza, C.D.K., Shem, M.N., Otsyina, R., Ichinohe, T. and Fujihara, T. (2003a). Nutritive evaluation of some browse tree legume foliages native to semi-arid areas in western Tanzania. Asian Aust. J. Anim. Sci. 16:1429-1437.

[24]. Salem, A.Z.M., Salem, M.Z.M., El-Adawy, M.M. and Robinson, P.H. (2006). Nutritive Evaluation of some browse Tree Foliages During the dry Season: Secondary Compounds, Feed Intake and in vivo Digestibility in Sheep and Goats. Animal Feed Science Technology, 127: 251-267.

[25]. SAS (2005) Institute Inc. SAS/STAT, Users’ Guide. 6.03 edition. Cary NC, USA.

[26]. Sawe, J.J., Tuitoek, J.K., and Ottaro, J.M. (1998). Evaluation of common Tree leaves or pods as Supplements for Goats on Range Area of Kenya. Small Ruminant Research, 28:31-37.

[27]. Sikosana, J.L.N., Smith, T., Mlambo,V., Owen, E., Muller-Harvey, I. and Mould, F. (2002). Acacia and other tree pods as dry season feed supplements for goats. In: (eds) smith, T., Godfrey, S.H., Buttery, P.J. and Owen. E. Helping Small Stock keepers enhance their livelihoods: Improving management of small holder owned sheep and goats by utilizing local resources: proceedings of the second DFID livestock production programme Link project (R7798) workshop for small stock keepers. Sokoine Universityof Agric. Tanzania 8-10 January, 2002 pp 69-75.

[28]. Sikosana, J. (2006). The Effects of Treated Acacia nilotica pods as Feed Supplement to Pregnant Indigenous Matebele Goats of Zimbabwe, grazing during the Dry Season, DFID R4D Report.

[29]. Tanner, T.C., Reed, J.D., and Owen, E. (1990). The nutritive value of fruits (Pods and Seeds) from Acacia species compared with extracted Nough (Guizonia abysinica) meal as supplement to maize stover for Ethiopian highland sheep. Anim. Prod. 51, 122-133.

[30]. Topps, J.A. (1992). Potential composition and use of legume shrubs and trees as fodder for livestock in the tropics (Review) Journal of Agricultural Science, Cambridge, 118: 1-8

[31]. Umunna, N.N., Osuji, P.O., Nsahlai, I.V., Khalili, H. and Mohammed-Saleem, M.A. (1995). Effect of Supplementing oat hay with lab lab, Sesbania, tagaste or wheat middlings on voluntary intake, nitrogen utilization and weight gain of Ethopian Menz sheep. Small Ruminant Research 18:1130-120.

[32]. Van Soest, P.J. (1994). Nutritional ecology of the ruminants ( $2^{\text {nd }}$ ed). Cornell University press, Ithaca, N.Y, USA.

[33]. Van Soest, P.J. and Robertson, J.B. (1988). Methods for dietary Fibre, neutral detergent fibre and non-starch polysaccharides in relation to animal nutrition. J. Dairy Sci. 74: 3583-3597.

[34]. Wikipedia, the free Encyclopedia - List of medical abbreviations: C.mhtml:file://F:/list\%20of\%20medical\%20abbreviations\%20(symbol)\%2007-05-14..mht. downloaded on $9^{\text {th }}$ May, 2014 pp 1-7

[35]. Wisloff, H., Flaoyen, A., Ottesen, N., and Hove, T. (2003). Narthecium Ossifragum (L.) Huds. causes of Kidney Damage in Goats: Morphological and Functional Effects. Veterinary Pathology, 40:317-327.

[36]. Yahaya, B. (2011). Evaluation of nutritive value of Acacia (Acacia seyal del.) fruits on performance of Yankasa sheep. M.Sc Thesis submitted to animal Sci. Dept. Ahmadu Bello University, Zaria, Nigeria. 